\title{
Guava Fruit Juice Red Increases Levels Pregnant Women's Hemoglobin in Bokin Health Center
}

\author{
Ludia Banne Allo ${ }^{1}$, Herman Tandilimbong ${ }^{2}$, Frans Manangsang ${ }^{3}$, Jenita DT Donsu ${ }^{4}$, Lamria Situmeang ${ }^{5}$, Agussalim ${ }^{6}$ \\ ${ }^{1}$ School of Midwifery, Midwifery Academy, Jalan Pramuka, Rantepao, North Toraja, South Sulawesi Province, Indonesia. \\ ${ }^{2}$ Tana Toraja School of Nursing, Tana Toraja Health Institute, Jalan Poros Rantepao-Tallunglipu, North Toraja, South Sulawesi Province. \\ ${ }^{3,5}$ School of Nursing, Jayapura Health Polytechnic, Jalan Padang Bulan 2, Hedam, Heram District, Jayapura City, Papua Province, Indonesia. \\ ${ }^{4}$ School of Nursing, Yogyakarta Health Polytechnic, Jalan Tata Bumi No 3, Banyuraden, Gamping, Sleman, Yogyakarta Province, Indonesia. \\ ${ }^{6}$ Parepare School of Nursing, Jalan Laupe, Bukit Harapan, Soreang, Parepare city, South Sulawesi Province, Indonesia.
}

*Corresponding author: Dr Agussalim, Parepare School of Nursing, Jalan Laupe, Bukit Harapan, Soreang, Parepare city, South Sulawesi Province, Indonesia

\begin{abstract}
One of the fruits that can increase hemoglobin levels is guava fruit, the chemical content in guava is amino acids (tryptophan, lysine), calcium, phosphorus, iron, sulfur, vitamin A, vitamin B1, and Vitamin C. High vitamin C content in guava can be used by pregnant women for the formation of red blood cells. The purpose of this study is to find out the effect of consuming pink guava fruit juice on the increase in hemoglobin levels of pregnant women who are anemic in Bokin Health Center (BHC) in 2017. The research method used is Pre-Experimental Design with the design used by One Group Pretest-Posttest and conducted from May 23 to August 23,2017 . The population in this study was 60 pregnant women who had anemia. The sampling method used is purposive sampling with the number of samples is 20 pregnant women who are anemic. The results of this study showed that the average hemoglobin of the mother before the consumption of guava juice is 9.9200 , while after the administration of guava juice obtained an average of 11.6650. From the test results paired t- test obtained a value of $\rho=0,000$. The value of $\rho$ is smaller than $ว(\rho=0.000$ replication $=$ 0.05), so Ho rejected Ha's acceptance. In conclusion, there is an effect of consuming pink guava juice on the increase in hemoglobin levels of pregnant women in BHC 2019. So, it is recommended that pregnant women can consume guava juice in order to prevent themselves from the occurrence of anemia, and it is expected to health officials to counsel about the benefits of guava juice content.
\end{abstract}

Keywords: Guava Juice; Hemoglobin; Pregnant Women; Anemia.

\section{Introduction}

Pregnancy is the growth and development of the fetus starting from conception and ending until the start of childbirth. The period of pregnancy is calculated from the first day of the last menstruation (HPHT) until the start of true childbirth, which marks the beginning of the antepartum period. The antepartum period is divided into three trimesters, each consisting of thirteen weeks or three months according to the calendar count. This time division is taken from a provision that considers that the length of pregnancy is estimated to be approximately 280 days, 40 weeks, 10 months (based on lunar or lunar rotation) or 9 months from the first day of the last menstruation (with an estimated 28-day cycle) [1]. This makes the pregnancy last approximately 266 days, 38 weeks (Fahira, 2017). Pregnancy is a condition that is very stretched against all kinds of stress that results in physiological changes as well as metabolic functions. In pregnancy there is also an increase in the need for energy and oxygen (suciani, 2015), where the placenta also contains many mitochondria that increase oxidative metabolic processes to produce energy that ultimately affects the continuity of a pregnancy process (Nurmadinisia, 2012). In pregnancy there is an increase in energy and oxidation needs (Wagey, 2011). In the process of pregnancy metabolism triggers physiological changes that obscure the diagnosis of a number of hematological abnormalities as well as their assessment [2]. One of the most meaningful changes is the increased use of oxygen from the mother's body, placenta and child development and when the number of red blood cells (erythrocytes) or oxygen carriers in the blood hemoglobin ( $\mathrm{Hb}$ ) is not sufficient for the physiological needs of the pregnant woman's body it will experience anemia Cunningham et al..

Anemia is a condition in which the body has too few red blood cells (erythrocytes), which red blood cells contain hemoglobin that 
serves to carry oxygen throughout the body tissues (Proverawati, 2013). An increase in plasma volume is the cause of physiological anemia in pregnancy. Increased plasma volume causes hematocrit, blood hemoglobin concentration, and the number of circulating erythrocytes to decrease but does not reduce the absolute amount of hemoglobin or the amount of erythrocytes in the overall circulation. Plasma volume begins to increase from the $6^{\text {th }}$ week of pregnancy but does not correspond to the number of red blood cells (erythrocytes) [3]. At its peak, plasma volume in pregnant women was $40 \%$ higher than in women who were not pregnant (Caroline, 2016). Anemia occurs in pregnant women due to insufficient production of red blood cells by factors of nutrient consumption, especially iron[4]. The formation of red blood cells depends on the supply of essential basic ingredients, some of which are not available in the body but must be provided through food. One of them is iron deficiency anemia, which occurs if not enough iron is available for the process of formation of hemoglobin (Ngurah Rai, 2016). According to the Regulation of the Minister of Health of the Republic of Indonesia number 88 of 2014 that to protect pregnant women from malnutrition and prevent the occurrence of iron nutrition anemia, pregnant women need to consume blood-added tablets. Standard blood-added tablets for women of childbearing age and pregnant women are given as much as one time a week and one time a day during menstruation and for pregnant women given daily during their pregnancy or at least 90 tablets. The absorption of iron is strongly influenced by the availability of vitamin $\mathrm{C}$ in the mother's body.

The role of Vitamin $\mathrm{C}$ can help reduce ferry iron ( $\mathrm{Fe} 3+$ ) to Ferro (Fe2+) in the small intestine so that it is easily absorbed, the reduction process will be greater when the $\mathrm{pH}$ in the stomach is getting acidic[5]. Vitamin C can increase acidity so that it can increase iron absorption by up to $30 \%$ (Sari, 2013). The government program that has been run is seen in the coverage figures of Fe tablets in pregnant women in Indonesia in 2012, nationally the coverage of pregnant women gets 90 Fe tablets by $86 \%$. The data almost reached the program target in 2012 of $90 \%$ (Ministry of Health, 2014). However, iron deficiency anemia in pregnant women is still a health problem experienced by women around the world, especially in developing countries (Ministry of Health, 2012). According to Wirawan S et al. that's administration of Fe tablets with the addition of vitamin C can help increase hemoglobin levels in pregnant women. One fruit that is very rich in vitamin $C$ is guava[6]. Vitamin $C$ content in guava is equivalent to 6 times the content of vitamin $\mathrm{C}$ in oranges, 10 times the content of vitamin C in papaya, 17 times the content of vitamin $C$ in guava, and 30 times the content of Vitamin C in bananas. (Hadieti and Apriyanti,2015). The World Health Organization (WHO) reports the prevalence of mothers with iron deficiency is about $35-37 \%$ increasing with the increase in gestational age and an estimated $30-40 \%$ cause of anemia due to iron deficiency[7]. This disorder is characterized by decreased serum iron (SI), Total Iron Binding Capacity (TIBC) increases, transferrin saturation decreases, serum ferritin decreases, bone marrow iron painting is negative and there is a response to treatment with iron preparations (WHO, 2013).
Based on the results of Basic Health Research in 2013, the prevalence of anemia in pregnant women in Indonesia by $37.1 \%$, this presentation decreased compared to $83.3 \%$ in 2011, after the administration of Fe tablets in Indonesia in 2012 by $85 \%$. Although the government has conducted an anemia prevention program in pregnant women by giving 90 fee tablets during the pregnancy period with the aim of lowering the rate of anemia of pregnant women, but the incidence of anemia is still high (Ministry of Health, 2013) [8]. South Sulawesi province based on SKRT in 1992 prevalence of nutritional anemia, especially in pregnant women ranged from $45.5-71.2 \%$ and in 1994 increased to $76.17 \% .14 .3 \%$ in Pinrang Regency and $28.7 \%$ in Soppeng Regency and the highest was in Bone 68.6\% (1996) and Bulukumba district at 67.3\% (1997). While the data report in Maros Regency, especially in Bantimurung Sub district, pregnant women's anemia in 1999 amounted to $31.73 \%$, in 2000 increased to $76.74 \%$ and in 2001 by $68.65 \%$ (Ridwan, 2004).Data obtained from the Health Office of South Sulawesi Province, from 23. 839 pregnant women who checked hemoglobin levels, there are pregnant women with hemoglobin levels of 8-11 Mg / $\mathrm{dl}$ there are 23,478 people (98.49 \%) and pregnant women with hemoglobin levels $8 \mathrm{mg} / \mathrm{dl}$ there were 361 people (1.15\%) (South Sulawesi Provincial Health Office, 2015) [9]. Based on the initial data taken at BHC obtained by pregnant women in 2015 as many as 327 people, who experienced anemia as many as 120 people (36.69\%), who experienced mild anemia with $\mathrm{Hb}$ levels of 9-10 gr\% as many as 78 people, moderate anemia with $\mathrm{Hb}$ 7-8 gr\% as many as 32 people, and severe anemia with a level of 7 gr\% as many as 10 people. in 2016 the number of pregnant women as many as 316 people, who experienced anemia as many as 98 people (31.01\%), who experienced mild anemia with $\mathrm{Hb}$ levels of 9-10 gr\% as many as 61 people, moderate anemia with Hb levels of 7-8 gr\% as many as 30 people, and severe anemia with a level of $7 \mathrm{gr} \%$ as many as 7 people. in 2017 pregnant women as many as 317 people, and who experienced anemia as many as 117 people (36.90\%), who experienced mild anemia with Hb levels of 9-10 gr\% as many as 79 people, moderate anemia with $\mathrm{Hb}$ 7-8 gr\% as much as 23 people, and severe anemia with a level of 7 gr\% as many as 15 people [10]. In 2018 pregnant women as many as 360 people, and who experienced anemia as many as 135 people (37.5\%), who experienced mild anemia with hb levels of 9-10 gr\% as many as 94 people, moderate anemia with Hb levels of 7-8 gr\% as many as 36 people, and severe anemia with a level of Severity $7 \mathrm{gr} \%$ as much as 5 people. (BHC, 2018).

\section{Statement of The Problem}

Based on the background, it can be formulated a problem that is "Is There Any Influence of Consuming Guava Juice Against Increased Hemoglobin Levels in Pregnant Women in Boking Health Center[11].

\section{Method of Research}

The type of research used is pre-Experimental Design research with the design used by One Group Pretest-Posttest Design, which is a pretest design to know the initial state of the subject before 
being treated so that researchers can know the condition of the subject before and after being given treatment whose results can be compared or seen changes (Setiawan and Prasetyo, 2015). Sampling techniques in this study is by means of Nonprobability sampling purposive sampling type that is the technique of sampling determination by selecting samples among the population so that the sample can represent the characteristics of previously known populations [12-15]. In other words, purposive sampling is a technique of determining samples with certain considerations or special selection.

\section{Result}

\section{Univariate Analysis}

\section{a) Characteristics of Respondents}

The number of samples studied was 20 people, using observation sheets that have been prepared in advance according to the required data. The data source used is primary data. The data obtained from the results of the study is then compiled in the form of frequency distribution table both independent variables and dependent variables as follows.

\section{Mother's Age}

From the results of the research that has been obtained based on the characteristics of respondents according to the age of the mother divided into two groups namely age diagnose 20 years and 20-35 years at BHC, it can be presented in the table as follows Table 1 Source Primary Data 2019. Based on table 1, it can be seen that out of 20 respondents, the highest number of respondents' age is 20-35 years as many as 18 people (90\%), while lower than 20 years as much as 2 people (10\%).

Table 1: Respondents' Characteristics based on age.

\begin{tabular}{|c|c|c|}
\hline Age (Years) & Frequency (N) & Percentage (\%) \\
\hline Ties 20 Years & 2 & 10 \\
\hline $20-35$ Years Old & 18 & 90 \\
\hline Total & 20 & 100 \\
\hline
\end{tabular}

\section{Education}

Table 2: Respondent Characteristics based on Education.

\begin{tabular}{|c|c|c|}
\hline Education & Frequency (N) & Percentage (\%) \\
\hline Elementary & 4 & 20 \\
\hline Junior School & 5 & 25 \\
\hline High School & 9 & 45 \\
\hline Bachelor degree & 2 & 10 \\
\hline Total & 20 & 100 \\
\hline
\end{tabular}

From the results of the research obtained based on the characteristics of respondents according to the education of mothers divided into four, namely, elementary, junior high, high school and bachelor at BHC, it can be presented in the table as follows Table 2 Source Primary Data 2019. Based on Table 2 can be seen from 20 respondents according to maternal education the highest number of high school as many as 9 people (45\%), and the lowest number of bachelor as many as 2 people $(10 \%)$.

\section{Occupation}

From the results of research that has been obtained based on the characteristics of respondents according to the work of mothers who are divided into two namely housewife and private worker at BHC, it can be presented in the table as follows Table 3 Source Primary Data 2019. Based on Table 3, it can be seen that out of 20 respondents by mother's job the highest number of housewife as many as 18 people (90\%), and the lowest number of private worker as many as 2 people $(10 \%)$.

Table 3: Respondents' Characteristics based on Occupation.

\begin{tabular}{|c|c|c|}
\hline Job & Frequency (N) & Percentage (\%) \\
\hline Housewife & 18 & 90 \\
\hline Private & 2 & 10 \\
\hline Total & 20 & 100 \\
\hline
\end{tabular}

\section{Hemoglobin (Hb)}

Based on the results of research that has been obtained based on the characteristics of respondents according to $\mathrm{Hb}$ pregnant women who are divided into two, namely increased and not increased in BHC, it can be presented in the table as follows Table 4 Source Primary Data 2019. Based on Table 4 can be seen that out of 20 respondents according to $\mathrm{Hb}$ pregnant women after being given guava juice there are 3 (15\%) pregnant women whose her Hb does not increase or are said to still have Anemia.

Table 4: Respondent Characteristics based on Hemoglobin Pregnant Women.

\begin{tabular}{|c|c|c|c|c|}
\hline Hb (gr \%) & Before & \% & After & \% \\
\hline Not increased & 20 & 100 & 3 & 15 \\
\hline Increased & 0 & 0 & 17 & 85 \\
\hline Total & 20 & 100 & 20 & 100 \\
\hline
\end{tabular}

\section{Bivariate Analysis}

Bivariate analysis is performed to determine the influence of dependent variables with independent variables. The statistic tests used are:

\section{a) Normality Test}

Normality test is used to prove that the data obtained is already distributed normally or not. This is done to determine the statistics to be used to analyze the data. The researchers then used the Kolmogorov-Smirnov Test using the SPSS program. The calculation results are as follows Table 5 Source Primary Data 2019. Based on the results obtained from the calculation of Kolmogorov-Smirnov Test obtained a $\mathrm{p}$ value for before giving guava juice is 0.466 
and after that is $0.353 \mathrm{Gm}$., it can be concluded that the data is distributed normally, and then the appropriate static test for use is paired $t$ test (Paired Sample t-Test).

Table 5: Normality Test Results Effect of Consuming Guava Juice.

\begin{tabular}{|c|c|c|}
\hline Hb & Sig (p) & a \\
\hline Before & 0,466 & 0,05 \\
\hline After & 0,353 & 0,05 \\
\hline
\end{tabular}

\section{b) Research Statistics Test}

Based on the results of research before and after conducted using the Simple Paired Test t-Test, the results of bivariate analysis can be seen as follows Table 6 Source Primary Data 2019. Based on the results of research that has been done before being given red guava fruit juice the average value of 9.9200 and after being given guava juice the average value is 11.6650 . From the results of bivariate analysis using paired sample test t-test obtained $\mathrm{p}$ value is 0.000 . This value is smaller than 0.05 , so Ho rejected Ha accepted means there is an influence of consuming guava juice on the increase in $\mathrm{Hb}$ levels of pregnant women who are anemic.

Table 6: The Effect of Consuming Red Guava Fruit Juice.

\begin{tabular}{|c|c|c|c|}
\hline Hb & Total (N) & Mean (Average) & P \\
\hline Before & 20 & 99,200 & 0,000 \\
\hline After & 20 & 116,650 & \\
\hline
\end{tabular}

\section{Discussion}

Based on the results of research is on the effect of consuming guava juice on increasing $\mathrm{Hb}$ levels of pregnant women at BHC on January 23 to July 23, 2019. Anemia in pregnancy is conditions in which pregnant women who have Hb activity levels of 11.00 gr / $\mathrm{dl}$. Anemia in pregnancy is most commonly encountered is anemia due to iron deficiency (Fe). In pregnant women anemia increases the frequency of complications in pregnancy and childbirth. In general, one of the causes of iron deficiency anemia is insufficient iron intake and inadequate absorption (Widyastuti, 2005 in Kris and Lia, 2015). The absorption of iron is strongly influenced by the availability of vitamin $\mathrm{C}$ in the mother's body. One fruit that is very rich in vitamin $\mathrm{C}$ is guava. Guava has five times more vitamin $\mathrm{C}$ content than the content of vitamin $\mathrm{C}$ in citrus fruits. In addition, the vitamin A content of this fruit is classified as high with a sugar content of $8 \%$. Pregnant women with regular consumption of 100 grams of guava per day can increase hemoglobin levels. This is in accordance with the findings of research conducted by Argana, et al. in showing that any increase in the frequency of consumption of foods containing vitain C 1 time will increase hemoglobin levels by $0.06 \mathrm{gr} / \mathrm{dl}$. That is, the more often a person consumes vitamin $\mathrm{C}$, the higher the hemoglobin level. Based on the results of research conducted in BHC, the average hemoglobin level of respondents before consuming guava juice is 9.9200 and after being given guava fruit juice the average value is 11.6650 , which means there is a change in hemoglobin levels. From the result obtained the value of $\rho$ is 0.000 . This value is smaller than $0.05(\rho=0,000$ mistreat $=$ 0.05), then Ho rejected Ha accepted, meaning there is an influence of consuming guava juice on the increase in hemoglobin pregnant women [16].

The results of this study are in line with research conducted by Esty and Emy (2007) on the influence of hemoglobin levels in pregnant women before and after consuming guava obtained a value of $\rho$-value of $0.002(\mathrm{o}=0.05)$. It shows that there is a change in hemoglobin levels in pregnant women before and after consuming guava in the Village Bandung District Ngrampal Sragen. Based on Nurul's research (2017) the average increase in pretest and posttest hemoglobin levels was 10.23 and 11, where the average value of the difference in hemoglobin levels before and after was 0.66 with a value of $p$-value $=0.026$ disagreement $\mathrm{s}(0.05)$. The conclusion is that there is an influence of guava juice on changes in hemoglobin levels in pregnant women who consume Fe tablets at the Pakualaman Health Center in Yogyakarta. One of the fruits that can increase hemoglobin levels is guava fruit, the chemical content in guava is amino acids (tryptophan, lysine), calcium, phosphorus, iron, sulfur, vitamin A, vitamin B1, and Vitamin C. mineral content in guava fruit can overcome people with anemia (red blood deficiency) because in the fruit guava contains also mineral substances that can facilitate the process of formation of red blood cell hemoglobin. It contains minerals such as magnesium, copper, and manganese [17]. Manganese is used by the body as a companion factor to the antioxidant enzyme, superoxide dismutase. The need for iron trimester pregnancy varies, in the first trimester the need for iron is actually lower than the period before pregnancy because pregnant women do not have menstruation and the fetus conceived does not need much iron. By the second trimester, the need for iron began to increase, at this time there was an increase in the number of red blood cells. In the third trimester, the number of red blood cells increased by $35 \%$, along with the increasing need for iron by $450 \mathrm{mg}$. red blood cell growth is caused by the increasing need for oxygen from the fetus. Iron absorptive can be enhanced by cobalt, inosin, etionin, vitamin C, HCL, succinate and other acid compounds. Acid will reduce ferry ions into Ferro and inhibit the formation of Fe complex with insoluble food (Gunawan, 2007). The need for iron in pregnant women is twice the normal needs of adults. The need begins the second trimester due to hypovolemic as a physiological adaptation of pregnancy [18]. During pregnancy, a pregnant woman stores iron approximately $1000 \mathrm{mg}$ including for fetal, placenta and mother's hemoglobin itself. (Irianto, 2014). Therefore, mothers need iron 1.5-3 mg per day especially trimester II and III (Hoffbrand and moss 2015).

Age is one of the factors that affect Hemoglobin levels. According to Atikah (2009) if the age of pregnant women is too young that is less than 16 years where the reproductive organs are not ready for fertilization and pregnant women over 35 years become a problem because with increasing age, there will be a decrease in the function of the organ that begins the aging process. Another factor affecting hemoglobin levels is education. In this study, the education of pregnant women who were respondents was the most highly 
educated in high school. According to Arianto (2014) education is a process of change towards adulthood. The knowledge possessed by the mother will influence her decisions and behavior. Mothers who have higher education will use rational considerations and knowledge about the nutritional value of food or physiology more prominently.

The tendency of higher education, the number of anemia events decreases. Education about anemia is not only obtained from formal education. Information about anemia can be obtained from television, radio, newspapers, magazines, health workers or through friends [19]. Nutrition education is one of the efforts to overcome the problem of nutrition in the community. The existence of education is expected to change behavior towards improving food consumption and nutritional status. The next factor that can affect hemoglobin according to Rukiyah (2010) is work, a type of work in the informal sector with a relatively heavier physical workload, causing a person to sweat a lot. This results in an increase in iron expenditure along with sweat. Pregnant and lactating women who have to do the workload need a lot of food for their health condition and for their energy needs, so the necessary nutrients must be fulfilled. In this study, most of the pregnant women who were respondents were housewives (IRT) as many as 18 respondents $(90 \%)$. Based on the above, the researchers assume that there is an influence of pink guava juice on changes in hemoglobin levels in pregnant women who are anemic, because the high content of vitamin $\mathrm{C}$ in guava can be used by pregnant women for the formation of red blood cells. However, the researchers observed that there were 3 pregnant women who had previously experienced anemia and were given pink guava juice for 7 days. At the time measured $\mathrm{Hb}$ the mother remained anemic. This is due to the mother's low level of education, thus affecting the mother's knowledge about consuming nutritious foods or fruits for increased levels of her $\mathrm{Hb}$, as well as work factors that are heavier physical workload, causing a person to sweat a lot, resulting in increased iron expenditure along with sweat.

\section{Research Limitation}

a) There are some respondents who do not understand about what anemia and hemoglobin are as well as the benefits of guava. Because pregnant women just get information about the content of the pink guava juice.

b) The time is very limited so that it adapts to the research activities.

c) Availability of the respondents studied.

d) It cannot mandate the abstinence of foods containing other iron.

\section{Summary}

Based on the results of the study on the influence of consuming guava juice on the increase in $\mathrm{Hb}$ levels of pregnant women in BHC on May 23 to August 23, 2019 obtained, then researchers can draw conclusions are as follows. a) There is a change in maternal hemoglobin levels before and after consuming guava juice, where the average value before is 9.9200 and the average value after is 11.6650 .

b) There is an effect of consuming pink guava juice on the increase in $\mathrm{Hb}$ levels of pregnant women in BHC, where the probability level is $p=0.000$ or pseverit 0.05 , Ho rejected and Ha accepted.

c) The result of this study is Ho rejected and Ha accepted, meaning there is an influence of consuming guava juice on the increase in $\mathrm{Hb}$ levels of pregnant women in BHC.

\section{Suggestion}

a) It is expected that health workers, especially midwives who are in BHC in order to provide information and counseling to pregnant women about the benefits of guava so that the mother does not experience anemia.

b) It is expected that the public can know especially mothers from the dangers of anemia, which can result in or lead to death. So that the community can prevent the occurrence of anemia by means of the community always follow the health counseling held by the personnel or the health office.

c) Another expected in pregnant women to increase their knowledge about the nutritional content of guava needed, so that the pregnant woman can prevent herself from the occurrence of anemia.

d) This research expected that the place of researchers does not limit the researchers to conduct research and to provide input for Health Centers in order to improve counseling to pregnant women who have anemia.

e) Also it is expected to continue research on the influence of guava consumption on increasing hemoglobin levels in pregnant women with a more adequate sample number to improve maternal and fetal health.

\section{Reference}

1. Almatzier (2010) Basic Principles of Nutrition Science. Jakarta Gramedia Pustaka Utama.

2. Asrinah (2010) Maternity Care During Pregnancy. In Ed. Yogyakarta Graha Ilmu.

3. Briawan D (2014) Anemia, Nutritional Problems in Adolescent Women. Jakarta EGC.

4. Dhita (2015) The Effectiveness of Guava Juice Against Changes in $\mathrm{Hb}$ Levels in Trimester Iii Pregnant Women in the Work Area of the Bacem Community Health Center, Blitar Regency. Journal of the Faculty of Health Sciences, Kadiri University.

5. Fahira A (2017) Risk Factors for Preeclampsia in Pregnant Women at Anutapura Hospital, Palu City. Tadulako Health Journal 3 (2) 1-75.

6. Gandasoerbrata R (2003) Penuntun Laboratorium Klinik. Bandung. Ida, great. 2016. Effects of Moringa Leaves on Growth and Development of Male White Rats. Journal of Symbiosis.

7. Iskandar I (2015) Effect of Moringa Oleifera Leaf Extracts Supplementation In Preventing Maternal Anemia And Low Birth Weight. IJSRP 5 (2): 1-3. 
8. Ministry of Health RI (2015) Prevalence of Pregnant Women in Indonesia. Jakarta: Indonesian Ministry of Health Research and Development Agency.

9. Kiswari R (2014) Hematology and Transfusion. Jakarta: Erlangga Kia Puskesmas Mawali.

10. Manuaba (2001) Kapital Selekta Routine Management of Obstetrics and Gynecology Kb. EGC Medical Book. Jakarta.

11. Manuaba (2010) Obstetrics and family planning diseases. Jakarta: EGC.

12. Putri Nurul Andiyani (2017) The Effect of Guava Juice on Changes in Hemoglobin Levels of Third Trimester Pregnant Women Who Consume Fe Tablets at Pakualaman Center Yogyakarta. Journal of the Faculty of Health Sciences, Aisyiyah University Yogyakarta.

13. Prawiroharjo S, Dan Winkjoastro H (1999) Obstetrics. Third Edition, Bina Pustaka Indonesia Jakarta.
14. Proverawati A (2013) Pregnancy Anemia and Anemia. Yogyakarta: Nuha Medika.

15. Proverawati A and Sulistiyorini. 2010. LBW (Low Birth Weight) Completed with Care for LBW and Infant Massage. Yogyakarta Nuha Medika.

16. Saidah Halimatus (2017) Effect of Combination of Red Guava Juice and Honey on Increasing Hb Levels in Pregnant Women. Faculty of Health Sciences, University of Kadiri.

17. Wasnidar (2007) Pocket Book of Anemia in Pregnant Women. Jakarta: Trans Info Media.

18. World Health Organization (2013) Guideline: Lintermittent Iron and Folic Acid Supplementation in Menstruating Women.

19. Yanti (2012) Image of Red Guava.

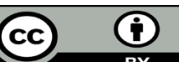

This work is licensed under Creative Commons Attribution 4.0 License

To Submit Your Article Click Here: Submit Article

DOI: $10.32474 /$ RRHOAJ.2021.06.000239

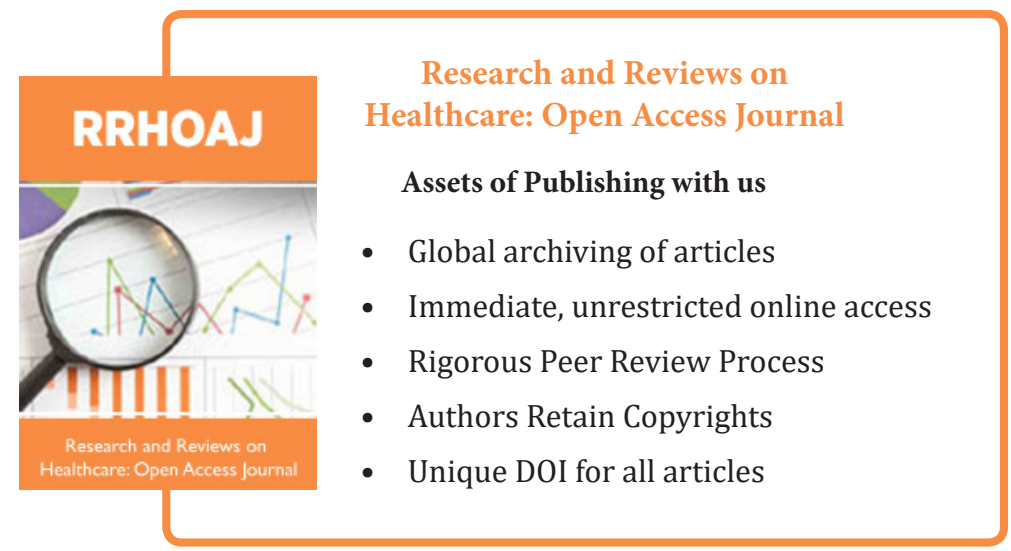

